\title{
EU Corporate Fines Hit the Wrong and Fail their Purpose: Empirical Considerations and their Consequences from the Perspective of Shareholders' Fundamental Rights
}

\section{Abstract}

Corporate fines are imposed on companies and geared to, and meant to hit, the compa$n y$, not the acting managers. While corporate fines leave the simultaneous enforcement against individual managers by fines (or other sanctions) unaffected, their size tends to move them in the foreground of law enforcement: Law enforcers, public treasurers and media are attracted by large figures. In addition, under EU law the Commission can impose fines, notably fines for EU competition law infringements, on companies only, not on individual managers. Over the last years, the amounts of national and EU corporate fines have increased steadily and indeed come to reach orders of magnitude relevant to the public treasuries to which these monies flow. However, economically speaking, corporate fines are borne by the shareholders. They are also meant to be borne by the shareholders. This is underscored where, as in most EU countries, domestic law denies companies to seek recourse against the managers for fines even where managers can be demonstrated to have been responsible for the illicit conduct, and even where the managers have circumvented the company's compliance barriers. Yet, the purpose of EU corporate fines is to act as deterrent and thus to influence the conduct of companies. However, conduct can be influenced in human individuals only. A company, in contrast, is a legal person and, physically speaking, a mere pile of paper filed with the company register. A pile of paper cannot be "deterred". This entails the question whether such fines unduly encroach upon the fundamental rights of those who are effectively hit by corporate fines, that is, the shareholders. The EU Charter of Fundamental Rights protects their property (including property in shares) and their econonomic freedoms. According to the ECJ, restrictions of fundamental rights must be proportionate: They must not be "manifestly unsuitable" to reach their purpose and they must "strike the right balance". The author has submitted elsewhere that corporate fines, analyzed in the framework of corporate, DEO and insurance law, fail to meet these standards and

* Rechtsanwalt and Attorney-at-Law (New York), Cologne; the author is a partner with GÖRG Partnerschaft von Rechtsanwälten in Cologne. The areas of emphasis of his practice include corporate law and compliance. Before his entry into private practice, he was general counsel to a large industrial corporation. 
thus, for legal reasons, violate the fundamental rights of shareholders: Shareholders are usually not responsible for the illicit conduct, and under corporate law they are typically unable to prevent recidivism. Against that background, this article analyzes the findings of recent empirical studies on the causes for law infringements committed in a corporate context. These findings show that managers engaging in illicit conduct are driven by factors detached from corporate fines. Hence, the studies, from an empirical perspective, support the view that corporate fines are a disproportionate restriction of shareholders' rights and thus unlawful. The article thus submits that major revisions in today's corporate fine practice are called for. This holds particularly true about the EU's mushrooming fines.

Keywords: Corporate fines, corporate law, fundamental rights, restrictions, shareholders, property

\section{Introduction and subject of the article}

1. Xerxes, the flogging of the Hellespont and corporate fines

When, on his invasion of Greece, Persian Great King Xerxes crossed the Hellespont in 480 B.C., his pontoon bridge suffered from a severe storm. The Great King felt this to be disrespect of his commands and had the waves of the Hellespont punished with 300 strokes of the rod. ${ }^{1}$ While one can understand Xerxes' anger about the Hellespont's challenge, today we consider foolish the Great King's sentiment and response. What has not changed to date, however, is the sentiment that violations of applicable rules must be punished. Yet, today sanctions must be measured agaist the fundamental rights of the punished and need to be justified by valid reasons. Broadly speaking, today we find such justification to be deterrence ${ }^{2}$, 3: Sanctions are to influence conduct. However, conduct can be influenced in human individuals only. In contrast, corporate fines

1 Herodotus, Histories, 7, 35; it was Bernd Schünemann who first pointed out the parallel between corporate sanctions and Xerxes' measure, in: On the question of unconstitutionality and the consequences of criminal law for undertakings, Expertise of November 2013 for the Family Business Foundation, https://www.familienunternehmen.de/media/public/pdf/ publikationen-studien/studien/Studie_Stiftung_Familienun-

ternehmen_Unternehmensstrafrecht.pdf, p. 13.

2 For purposes of German law: A. Reuter, Unternehmensgeldbußen, Organregress, Grenzen der Versicherbarkeit und Gesellschaftsrecht: Eine systemische Verletzung der Grundrechte der Anteilseigner?, Betriebs-Berater 2016, 1283; A. Reuter, Unternehmensbußen - ein verfassungsrechtlicher Holzweg, Zeitschrift für Wirtschaftsrecht (ZIP) 2018, 2298; A. Reuter, Schadensersatz und Bußgelder zu Lasten des Unternehmens bei Ad hoc-Pflichtverstößen: Ein Verstoß gegen die Grundrechte und die Treuepflicht der Aktionäre?, Neue Zeitschrift für Gesellschaftsrecht 2019, 321. For purposes of EU law, see A. Reuter, Systematically Flogging the Wrong: EU Corporate Fines Violate the Fundamental Rights of Shareholders - The European Commission as Revenant of the Persian Great King Xerxes, European Business Law Review, scheduled to appear in issue 4/2021; A. Reuter, Flogging the Wrong: EU Corporate Fines Violate the Fundamental Rights of Shareholders, Journal of European Competition Law \& Practice, lpaa052, https://doi.org/10.1093/jeclap/lpaa052. 
are imposed on companies, and a company is a legal person and, physically speaking, a mere pile of paper filed with the commercial register. A pile of paper, in turn, is as unsusceptible to fines as the Hellespont's waves. In the economic reality, the human individuals who bear the burden of coporate fines are the shareholders, not the acting human individuals, that is, the managers. In addition, under civil law, companies are usually prevented from seeking recourse against managers; this shows that corporate fines are meant to be economically borne by the shareholders, not the managers. Yet, the shareholders have typically not participated in, or instigated, the law infringements which were the cause of the sanctions. In addition, in many instances corporate law expressly cuts shareholders off from the management of the company. As a rule, this is the case in respect of stock corporations which bestow the task of managing the company on the management board to the exclusion of (majority and minority) shareholders. $^{4}$

All of this indicates a basic and inherent flaw in the system of corporate fines: They hit the shareholders who, however, in many in many instances (a) have no part in the sanctioned law infringement, (b) are, under corporate law, unable to prevent recidivism and (c) do not "deserve" sanctions as they have not engaged in illicit conduct: Investing in companies is lawful and, for many citizens, forms part of their old age and emergency planning, no matter whether they invest directly or via pension schemes, life insurers or similar organizations. ${ }^{5}$ If, however, a government act impairs citizens (here: the shareholders), but fails to achieve a valid purpose, this gives rise to the question whether such act is compatible with the fundamental rights of the affected citizens. Where corporate sanctions are imposed by the EU, this is an issue of EU fundamental rights, notably the EU Charter on Fundamental Rights. Where corporate sanctions are imposed by an EU member state, this is an issue of the protection of fundamental rights under that state's laws. Where corporate sanctions are imposed by an EU member state in the implementation of EU law, this is an issue of both the EU Charter on

3 It should be clarified at the outset that the article does not address the effects of economic benefits flowing to a company out of a law infringement. Companies are not entitled to such benefits and must not keep them. However, corporate fines are not limited to the confiscation of such benefits but are meant to exceed them substantially so as to "deter" companies from further infringements. Furthermore, under EU law corporate fines are determined irrespective of any compensation which the company in question owes and pays to third parties. Hence, the issues of corporate fines and confiscation of benefits are to be treated separately.

4 For a more detailed analysis A. Reuter, Unternehmensgeldbußen, Organregress, Grenzen der Versicherbarkeit und Gesellschaftsrecht: Eine systemische Verletzung der Grundrechte der Anteilseigner?, Betriebs-Berater 2016, 1283, 1285 et seq.; A. Reuter, Systematically Flogging the Wrong: EU Corporate Fines Violate the Fundamental Rights of Shareholders, European Business Law Review, scheduled to appear in issue 4/2021, sections I and II.

5 That function of ensuring personal autonomy and security has been given addition weight by the European Central Bank's long-term low interest policy; see A. Reuter, Unternehmensgeldbußen, Organregress, Grenzen der Versicherbarkeit und Gesellschaftsrecht: Eine systemische Verletzung der Grundrechte der Anteilseigner?, Betriebs-Berater 2016, 1283 , 1290; Systematically Flogging the Wrong: EU Corporate Fines Violate the Fundamental Rights of Shareholders, European Business Law Review, scheduled to appear in issue 4/2021, sections I and II. 
Fundamental Rights and national fundamental rights ${ }^{6}$. Indeed, the author has argued elsewhere that corporate sanctions under German law on the one hand and under EU law (notably corporate fines for competition law infringements under TFEU art. 103) on the other, systemically violate the fundamental rights of shareholders under German law ${ }^{7}$ and under EU law ${ }^{8}$, respectively: Corporate fines hit the wrong and thus (1) are manifestly unsuitable to achieve their purpose and (2) do not strike the right balance.

It is true that in many decades of its practice, the European Court of Justice ("ECJ") has never objected to corporate fines from that perspective. Yet, the analysis of these doubts is neither academic nor moot: The limits set by shareholders' fundamental rights is a "fresh issue of law" which has never been brought before, and dealt with by, the ECJ. It can, under the ECJ's procedural rules, thus be raised at any time'. This holds all the more so in view of the increased significance attached to EU fundamental rights and the mushrooming amounts of the fines which the Commission has come to impose in the last decade. ${ }^{10}$ Severely hitting the wrong, corporate fines are even more despotic than flogging waves who feel - unlike shareholders - no pain.

6 ECJ, 26.02.2013, Case C-399/11 (Melloni); 26.02.2013, Case C-396/11 (Radu); 18.06.2013, Case C-681/11 (Schenker); 26.02.2013, Case C-617/19 (Akerberg-Fransson); for an extensive overview G. Dannecker, Der Grundrechtsschutz im Kartellordnungswidrigkeitenrecht im Lichte der neueren Rechtsprechung des EuGH, Nene Zeitschrift für Kartellrecht 2015, 25, 26; M.Böse, Das Unternehmensstrafrecht im Spiegel völker- und unionsrechtlicher Vorgaben, in M.Jahn / C. Schmitt-Leonardy / G. Schoop (ed.), Das Unternehmensstrafrecht und seine Alternativen, Baden-Baden 2016, p. 88, 104 ff.; G. Dannecker / C. Dannecker, Europäische und verfassungsrechtliche Vorgaben für das materielle und formelle Unternehmensstrafrecht, Newe Zeitschrift für Wirtschaftstrafrecht, 2016, 162, 165 ff.; A. Reuter, Schadensersatz und Bußgelder zu Lasten des Unternehmens bei Ad hoc - Pflichtverstößen: Ein Verstoß gegen die Grundrechte und die Treuepflicht der Aktionäre?, Neue Zeitschrift für Gesellschaftsrecht 2019, 321, 331/332.

7 See note 2 above and Chapter II below.

8 See note 2 above and Chapter II below.

9 ECJ, 5 March 1986, Case 69/85, Wünsche Handelsgesellschaft GmbH \& Co. v. Germany, para. 15; for a more detailed analysis, A. Reuter, Flogging the Wrong: EU Corporate Fines Violate the Fundamental Rights of Shareholders, Journal of European Competition Law \& Practice, lpaa052, https://doi.org/10.1093/jeclap/lpaa052, section III 5.

10 C. Bellamy sets out that fines running into millions are a feature of "modern competition law" which has been "inconceivable" when the Treaties were originally signed. In addition, a heavy EU fine "increasingly carries a considerable stigma, both for the undertaking and the employees involved"; furthermore, in some jurisdictions the conduct in question is formally criminalised; and there is the increasing likelihood of "follow on" civil actions, C. Bellamy, ECHR and competition law post Menarini: An overview of EU and national case law, $e-$ Competitions, N47946, 5 July 2012. 
2. Subject of the article: Empirical support to the view that corporate fines are disproportionate

While briefly sketching out that legal analysis in Chapter II, the focus of the present article is to address the empirical question of whether corporate fines have a factual effect on the acting human individuals, that is, the managers. To this end, after setting out the irrelevance of the distinction between "administrative" and "criminal" fines for purposes of this article (Chapter III), the article analyzes recent empirical findings on the causes for "corporate" law infringements: To begin with, Chapter IV sets forth the denial by the German Monopolies Commission of the actual effect of ever increasing corporate fines. Chapter $\mathrm{V}$ analyzes a broad panoply of further studies on the causes which lead to corporate wrongdoing. These studies show that managers, engaging in illicit conduct, are driven by factors detached from corporate fines. Chapter VI discusses whether that finding neglects the inherent "profit orientation" of companies and shareholders, and whether a "criminogenic" character of that orientation could off-set the described lack of empirical suitability. Chapter VII discusses the impact of the considerations of the economic theory of law. In its conclusion in Chapter VIII, the article submits that the described empirical findings support the view that corporate fines constitute a disproportionate restriction of the fundamental rights of shareholders, and, on that basis, suggests practical consequences to be drawn from this finding.

\section{Infringement of shareholder's rights for legal reasons}

1. Corporate fines as disproportionate restriction of shareholders' fundamental rights

The author has argued elsewhere that, in his view, corporate sanctions systemically violate the fundamental rights of shareholders ${ }^{11}$. This article thus confines itself to the following sketch of the line of argument:

(1) Against the yardstick of fundamental rights, corporate sanctions and their justification cannot be assessed without regard to their effects. Both in economic terms and in terms of corporate, D\&O liability and insurance law, these effects occur with the shareholders. That the rights of those parties which are effectively impaired need to be at the heart of the legal analysis is also commensurate to, and supported by, the ECJ's case-law under which corporate fines cannot only be imposed on the very legal entity which has infringed the law, but on all companies which constitute an "economic unit" with the acting legal entity. ${ }^{12}$ Likewise, the amount of corporate fines is measured on the basis of the turnover of the entire group of companies to which the acting compa-

11 See note 2 above.

12 H. Achenbach, Die Einführung einer „unternehmensgerichteten Sanktion“ und einer Ausfallhaftung im Kartellordnungswidrigkeitenrecht durch die 9. GWB-Novelle, Zeitschrift für Wirtschafts- und Stenerstrafrecht (wistra) 2018, p. 185, $186 \mathrm{f}$. 
ny belongs, not only on the basis of the acting company's turnover. ${ }^{13}$ In other words, to effectuate the prosecution of competition law infringements, the ECJ does not only "pierce" the corporate veil, it removes it in its entirety. If EU law thus applies an economic approach in the interest of "effective" prosecution and fining, nothing else can hold true about "effective" protection of fundamental rights. Correspondingly, the issue whether or not corporate fines are compatible with fundamental rights of EU citizens must also be analysed in repect of the EU citizens effectively burdened by the fine. Those are the shareholders. ${ }^{14}$ (2) Hence, shareholders' fundamental rights and freedoms under both EU and national law must be taken into account; this holds particularly true as shares serve many groups of persons, life insurers, pension schemes and comparable organisations to provide for old age and emergency and/or personal life planning. While this may not hold true of judges and other civil servants (whose pensions are safely tax financed), for many other citizens shares constitute an essential financial pillar of their personal freedom. The importance of that function has been reinforced by the European Cental Bank's low interest rate policy. ${ }^{15}$ (3) Therefore, corporate fines must respect the principle of proportionality (not ony in respect of the company, but, even more importantly) vis-a-vis shareholders. ${ }^{16}$ To be proportional, a measure must, to begin with, be suitable (according to the ECJ: it must not be "mani-

13 ECJ, 11 December 2007, Case C-280/06, ETI, para. 41 and case-law cited; ECJ, 14 March 2019, Case C-724/17 - Skanska, para. 45..

14 For purposes of German law: A. Reuter, Unternehmensgeldbußen, Organregress, Grenzen der Versicherbarkeit und Gesellschaftsrecht: Eine systemische Verletzung der Grundrechte der Anteilseigner?, Betriebs-Berater 2016, 1283, 1287/8; A. Reuter, Unternehmensbußen ein verfassungsrechtlicher Holzweg, Zeitschrift für Wirtschaftsrecht (ZIP) 2018, 2298, 2300. For purposes of EU law, see A. Reuter, Systematically Flogging the Wrong: EU Corporate Fines Violate the Fundamental Rights of Share-holders - The European Commission as Revenant of the Persian Great King Xerxes, European Business Law Review, scheduled to appear in issue 4/2021; A. Reuter, Flogging the Wrong: EU Corporate Fines Violate the Fundamental Rights of Shareholders, Journal of European Competition Law E Practice, lpaa052, https://doi.org/10.1093/jeclap/lpaa052, section III C.

15 Ibid.

16 For purposes of German law: A. Reuter, Unternehmensgeldbußen, Organregress, Grenzen der Versicherbarkeit und Gesellschaftsrecht: Eine systemische Verletzung der Grundrechte der Anteilseigner?, Betriebs-Berater 2016, 1283, 1287/8; A. Reuter, Unternehmensbußen ein verfassungsrechtlicher Holzweg, Zeitschrift für Wirtschaftsrecht (ZIP) 2018, 2298, 2302; A. Reuter, Schadensersatz und Bußgelder zu Lasten des Unternehmens bei Ad hocPflichtverstößen: Ein Verstoß gegen die Grundrechte und die Treuepflicht der Aktionäre?, Nene Zeitschrift für Gesellschaftsrecht 2019, 321, 322-328. For purposes of EU law, see A. Reuter, Systematically Flogging the Wrong: EU Corporate Fines Violate the Fundamental Rights of Share-holders - The European Commission as Revenant of the Persian Great King Xerxes, European Business Law Review, scheduled to appear in issue 4/2021; A. Reuter, Flogging the Wrong: EU Corporate Fines Violate the Fundamental Rights of Shareholders, Journal of European Competition Law E Practice, lpaa052, https://doi.org/10.1093/jeclap/ lpaa052, section III C. 
festly unsuitable") to achieve the objective in question. ${ }^{17}$ (4) The objective of sanctions is to work as a deterrent, that is, to influence behaviour. ${ }^{18}$ (5) However, under many corporate regimes (in particular in stock corporations) shareholders do not have the possibility to prevent law infringements as the law tasks the management, to the exclusion of the shareholders, with the company's operations. Similar settings exist under the corporate governance rules of other types of company as (a) shareholders are not obligated to control their company, (b) not all shareholders may be involved and/or have control rights in the company's operations (in particular minority shareholders) and (c) where shareholders effectively run the management, it would be possible to fine the responsible shareholders directly and not resort to corporate fines which affect all shareholders, irrespective of their say and responsibility, on a pro rata shareholding basis which has nothing to do with their involvement in the illicit conduct. ${ }^{19}$ (6) Thus, as corporate fines hit the shareholders, these fines are manifestly unsuitable to reach their objective: How should shareholders behave differently if corporate law cuts them off from management?20 (7) In addition, being economically hit for law infringements committed by managers, shareholders are held liable for faults of others ("kin responsibility" or "Sippenhaft"). This holds all the truer where the management is legally insulated against recourse. ${ }^{21}$ In such a setting, corporate fines allow the responsible managers to laugh up their sleeves, gravely embitter the wrongly burdened shareholders and undermine the trust in the legal system. Hence, corporate fines are not only "manifestly unsuitable" but, in terms of the ECJ'c case-law on the proportionality test, "do not strike the right balance". This holds particulary true where (i) shareholders have taken due care in selecting the management, (ii) requested the management to be com-

17 For purposes of EU law, see A. Reuter, Systematically Flogging the Wrong: EU Corporate Fines Violate the Fundamental Rights of Share-holders - The European Commission as Revenant of the Persian Great King Xerxes, European Business Law Review, scheduled to appear in issue 4/2021; A. Reuter, Flogging the Wrong: EU Corporate Fines Violate the Fundamental Rights of Shareholders, Journal of European Competition Law \& Practice, lpaa052, https://doi.org/10.1093/jeclap/lpaa052, section III D.

18 See Chapter III 2.

19 For purposes of German law: A. Reuter, Unternehmensgeldbußen, Organregress, Grenzen der Versicherbarkeit und Gesellschaftsrecht: Eine systemische Verletzung der Grundrechte der Anteilseigner?, Betriebs-Berater 2016, 1283, 1290, 1293. For purposes of EU law, see A. Reuter, Systematically Flogging the Wrong: EU Corporate Fines Violate the Fundamental Rights of Share-holders - The European Commission as Revenant of the Persian Great King Xerxes, European Business Law Review, scheduled to appear in issue 4/2021; A. Reuter, Flogging the Wrong: EU Corporate Fines Violate the Fundamental Rights of Shareholders, Journal of European Competition Law E Practice, lpaa052, https://doi.org/10.1093/jeclap/ lpaa052, section III A, III C 5.

20 Ibid.

21 Ibid.; in respect of the denial of recourse see the overview in A. Reuter, Flogging the Wrong: EU Corporate Fines Violate the Fundamental Rights of Shareholders, Journal of European Competition Law E Practice, lpaa052, https://doi.org/10.1093/jeclap/lpaa052, sections III A, IV; A. Reuter, Systematically Flogging the Wrong: EU Corporate Fines Violate the Fundamental Rights of Share-holders - The European Commission as Revenant of the Persian Great King Xerxes, European Business Law Review, scheduled to appear in issue 4/2021. 
pliant, and (iii) companies are prevented by domestic law from seeking recourse against the reponsible managers and from taking out insurance against fines. ${ }^{22}$ (8) Thus, corporate fines disporortionately restrict the fundamental rights of shareholders as a matter of law. ${ }^{23}$

\section{2. "Risk allocation" as sufficient basis for corporate fines?}

It should be added that the described economic sanctioning of the shareholders cannot be justified by the argument that corporate fines simply constitute a materialization of an operational risk and that such risk is embedded in the investment in the shares: To begin with, corporate fines differ from economic fluctuations (economic risk), from general tax, legislative or political changes (political risk) and damages resulting from management action (be it lawful business decisions, be it law infringements or other violations of care by company personnel) because corporate fines constitute a deliberate and specific "evil" imposed by government or EU Comission on the company and thus on the shareholders. That effect on the shareholders is not an unforeseen side effect or accidental circumstance, but an inevitable corollary of the fine. This holds (not only, but) particularly true where the company is denied both (i) seeking recours against the actually responsible managers and (ii) taking out insurance against corporate fines. Hence, as government / Commission acts, they must, unlike business risks, be measured against the rights of the shareholders. Thus, they must be justified by their pupose. However, the purpose of fines is not to impose an economic evil as a mere "business risk", but to effect deterrence. To be proporationate, they must be suitable to reach their purpose, just as any other government or Commission act. If, in contrast, corporate fines fail their purpose of deterrence, the restriction of shareholders' rights which they bring about cannot be justified as "bad luck" for the shareholders, or a risk "automaticially" associated with (or commensurate to) the intended rewards (dividends, stock price increases) of the investment. ${ }^{24}$

22 For purposes of German law: A. Reuter, Unternehmensgeldbußen, Organregress, Grenzen der Versicherbarkeit und Gesellschaftsrecht: Eine systemische Verletzung der Grundrechte der Anteilseigner?, Betriebs-Berater 2016, 1283, 1290 et seq.; A. Reuter, Unternehmensbußen - ein verfassungsrechtlicher Holzweg, Zeitschrift für Wirtschaftsrecht (ZIP) 2018, 2298, 2302 et seq.For purposes of EU law, see A. Reuter, Systematically Flogging the Wrong: EU Corporate Fines Violate the Fundamental Rights of Share-holders - The European Commission as Revenant of the Persian Great King Xerxes, European Business Law Review, scheduled to appear in issue 4/2021; A. Reuter, Flogging the Wrong: EU Corporate Fines Violate the Fundamental Rights of Shareholders, Journal of European Competition Law E Practice, lpaa052, https://doi.org/10.1093/jeclap/lpaa052, section IV.

23 Ibid.

24 See A. Reuter, Unternehmensgeldbußen, Organregress, Grenzen der Versicherbarkeit und Gesellschaftsrecht: Eine systemische Verletzung der Grundrechte der Anteilseigner?, $B e-$ triebs-Berater 2016, 1283, 1292. 


\section{III. "Administrative" versus "criminal" fines}

\section{Background}

Historically, "fines" as criminal sanctions, are based on the responsibility (guilt) of, and thus addressed to, human individuals. However, following the US, the classic country of "corporate fines", there is a broad tendency additionally to subject companies to fines. ${ }^{25}$ Some countries categorize such sanctions to be "criminal", some categorize them as "administrative" and other countries adopt a course in between. Germany has, in the past, followed the administrative approach by way of its Ordnungswidrigkeitengesetz; that concept was criticized as outdated and thus the German legislator presently intends to adopt a "Verbandssaktionengesetz". While that bill recoils from categorizing the fines as criminal or administrative, it increases the range of fine amounts drastically, namely to the EU level of up to $10 \%$ of the group turnover. ${ }^{26}$ The German legislator thus also does not only "pierce", but economically removes, the corporate veil in exacting corporate sanctions.

\section{Corporate Fines under EU law}

The EU, in turn, may, generally speaking, only introduce and sanction criminal offences within the framework of art. 325 of the Treaty on the Functioning of the European Union ("TFEU") for purposes of the protection of the EU's financial interests; however, the EU has not made use of this competence. However, TFEU art. 101 to 103 empower the European Commission to impose corporate fines to sanction competition law infringements. On the basis of these rules, the European Commission has come to impose the by far highest corporate fines in Europe which in recent cases exceeded Euro 1 billion. ${ }^{27}$

Despite their size and despite their importance for the EU's budget, EU law does not consider fines under $E U$ law to have a criminal character, but to be administrative

25 For an overview of the historical, international development, see M. Engelhart, Unternehmensstrafbarkeit im europäischen und internationalen Recht, EuCrim 2012, 110 et seq.; M. Engelhart, Verbandsverantwortlichkeit - Dogmatik und Rechtsvergleichung, Neue Zeitschrift für Wirtschaftsstrafrecht, 2015, $201 \mathrm{ff}$;; M. Kubiciel, Die deutschen Unternehmensgeldbußen: Ein nicht wettbewerbsfähiges Modell und seine Alternativen, Neue Zeitschrift für Wirtschaftstrafrecht 2016, 178.

26 https://www.bmjv.de/SharedDocs/Gesetzgebungsverfahren/Dokumente/RefE_Staerkung_I ntegritaet_Wirtschaft.pdf;jsessionid=F50AD9127108F5AA750554DCECFE271F.2_cid289? _blob=publicationFile $\& v=1$; for a detailed review of the bill see T. Brouwer, Objektive Gefährdungshaftung mit Zwang zur Kooperation?, Die Aktiengesellschaft, 2019, 920 et seq.

27 See the Commission's cartel statistics, https://ec.europa.eu/competition/cartels/statistics/ statistics.pdf, and ths table "Ten highest cartel fines per undertaking (since 1969)" contained therein. 
in nature. ${ }^{28}$ As set forth in TFEU art. 103 (2) lit. a), their purpose is "to ensure compliance with the prohibitions laid down in [TFEU] Article 101(1) and in Article 102". On this basis, art. 23 of Regulation (EC) No. 1/2003 (as its forerunner, Regulation 17/1962) empowers the European Commission "by decision [to] impose fines on undertakings and associations of undertakings where, either intentionally or negligently" competition rules have been infringed. Recital (29) of Regulation 1/2003 sets out the purpose of fines by stating forth that "[c]ompliance with Articles [101] and [102] of the Treaty and the fulfilment of the obligations imposed on undertakings and associations of undertakings under this Regulation should be enforceable by means of fines and periodic penalty payments. To that end, appropriate levels of fine should also be laid down for infringements of the procedural rules." Hence, fines are to induce stricter compliance by undertakings and to act as a special and/or general deterrent. In line therewith, the ECJ considers fines to "constitute an instrument of the Commission's competition policy" and set forth that they are to be fixed in a fashion so that they "may channel the conduct of undertakings towards observance of the competition rules" ${ }^{29}$ The goal to direct the conduct of undertakings is confirmed by the guidelines adopted by the European Commission on the method of setting fines imposed pursuant to Article 23(2)(a) of Regulation No $1 / 2003^{30}$ para. 4 of which sets forth:

The Commission's power to impose fines on undertakings or associations of undertakings which, intentionally or negligently, infringe Article [101] or [102] of the Treaty is one of the means conferred on it in order for it to carry out the task of supervision entrusted to it by the Treaty. That task not only includes the duty to investigate and sanction individual infringements, but it also encompasses the duty to pursue a general policy designed to apply, in competition matters, the principles laid down by the Treaty and to steer the conduct of undertakings in the light of those principles .... For this purpose, the Commission must ensure that its action has the necessary deterrent effect .... Accordingly, when the Commission discovers that Article [101] or [102] of the Treaty has been infringed, it may be necessary to impose a fine on those who have acted in breach of the law. Fines should have a sufficiently deterrent effect, not only in order to sanction the undertakings concerned (specific deterrence) but also in order to deter other undertakings from engaging in, or continuing, behaviour that is contrary to Articles [101] and [102] of the EC Treaty (general deterrence)" (emphases provided).

Furthermore, para. 37 sets out

"Although these Guidelines present the general methodology for the setting of fines, the particularities of a given case or the need to achieve deterrence in a particular

28 M. Ludwigs in Grabitz / Hilf / Nettesheim (ed.), Das Recht der Europäischen Union, loose leaf, status February 2020, AEUV, art. 103, para. 21/22; Bechtold / Bosch / Brinker, EUKartellrecht, 3rd. ed. 2014, art. 103 AEUV, para. 8.

29 ECJ, 6 April 1995, Cs. T-150/89, Martinelli v. Commission, para. 59; similar 6 October 1983, Joined Cases 100-103/80, Musique Diffusion Francaise, para. 109.

30 Guidelines on the method of setting fines, OJ C210, 1 September 2006, p.2-5. 
case may justify departing from such methodology or from the limits specified [above]" (emphasis provided)

and makes provision for fines and periodic penalty payments ${ }^{31}$. In the words of the ECJ, the competition rules "are intended to punish anticompetitive behaviour on the part of undertakings and to deter them from engaging in such conduct" 32 . Hence, corporate fines are meant to "punish" and to exert influence on the conduct of companies. It is worthy of note that under EU law, fines for competition law infringements can be imposed on undertakings and associations of undertakings only, not on corporate officers, other managers or other individuals acting on behalf, or in the interest, of the relevant undertaking: Art. 23 of Regulation (EC) No 1/2003 (as its forerunner, Regulation 17/1962) empowers the European Commission "to] impose fines on undertakings and associations of undertakings where, either intentionally or negligently competition rules have been infringed". There is no corresponding provision for individuals.

In an effort to have its rules enforced on an EU wide basis, to an increasing extent, the EU obliges the EU Member States to provide for sanctions against companies when transposing EU directives into national law, e.g. in the Second Protocol to the Convention on the Protection of the European Communities' Financial Interests and the Directives against Trafficking in Human Beings, Sexual Exploitation of Children, Participation in Criminal Organisations, Bribery in the Private Sector, in the area of capital market law, and in the Basic Data Protection Regulation. ${ }^{33}$ In that context, it is common ground that it is within the province of Member States to decide whether they impose "criminal" oder "administrative" fines on companies as long as the fines in question are "effective". ${ }^{4}$

31 Pursuant to art. 23 (2) subpara. 2 of Regulation (EC) No. 1/2003, fines may not exceed 10\% of the total turnover of the "undertaking", that effectively is, the group to which the relevant company belongs. Fines geared to the total group turnover, rather than to the turnover of the relevant company with the relevant products, demonstrate that EU fines are not to skim-off profits but to function as overarching deterrent.

32 ECJ, 14 March 2019, Case C-724/17, Skanska, para. 45.

33 Fo a detailed overbiew see M. Engelhart, Verbandsverantwortlichkeit - Dogmatik und Rechtsvergleichung, NZWiSt, 2015, 201 ff.; G. Dannecker / C. Dannecker, Europäische und verfassungsrechtliche Vorgaben für das materielle und formelle Unternehmensstrafrecht, Nene Zeitschrift für Wirtschaftstrafrecht, 2016, 162 et seq.

34 Communication of 20 September 2011 from the Commission to the European Parliament, the Council, the European Economic and Social Committee and the Committee of the Regions, 'Towards a European criminal justice policy: Ensuring the effective implementation of EU policies through criminal law', KOM(2011) 573 final, ec.europa.eu/justice/criminal/files/ act_de.pdf; M. Engelhart, Unternehmensstrafbarkeit im europäischen und internationalen Recht, EuCrim 2012, 110, 111 et seq.; A. Reuter, Schadensersatz und Bußgelder zu Lasten des Unternehmens bei Ad hoc - Pflichtverstößen: Ein Verstoß gegen die Grundrechte und die Treuepflicht der Aktionäre?, Neue Zeitschrift für Gesellschaftsrecht, 2019, 321, 332. 
3. No relevance of the distinction in the present context

For purposes of fundamental rights, it does, however, not play a role whether legislators give corporate sanctions a "criminal", an "administrative" or an intermediate form. This holds true both empirically and legally: The empirical studies to be discussed here show that the minds of managers breaching the law are detached from corporate fines, and the studies contain no indication that this finding is impacted in any way by such fines' dogmatic qualification under the applicable law. Most managers may not even be aware of such fine dogmatic distinctions. Likewise, from the legal perspective of shareholders' fundamental rights, it is the amount of the fine which determines the burden on the shareholders and thus the restriction of their rights, not the fine's dogmatic qualification. Likewise, decisions of the Commission imposing fines in competition cases are considered to involve a "criminal charge" for the purposes of Article 6(1) of the European Convention for the Protection of Human Rights and Fundamental Freedoms (ECHR) and art. 47, 52(3) of the EU Charter on Fundamental Rights: Under the case law of the European Court of Human Rights (which is followed by the ECJ), in deciding whether proceedings concerning misconduct are to be categorised as 'criminal' or not, the so-called three 'Engel criteria' have to be followed, so named after the judgment in which they were first formulated (Engel v. The Netherlands $)^{35}$ : First, there is the formal classification in the legal system concerned, but that is regarded explicitly as 'no more than a starting point'. In Engel, as in subsequent judgments, the European Court of Human Rights accorded significantly more importance - to the extent of disregarding the national law classification - to its second and third criteria, namely, the nature of the offence and the degree of severity of the penalty that the person concerned risks incurring. It has, in that regard, considered it relevant whether the penalty is imposed under a general rule addressed to all citizens rather than to a group possessing special status and whether it is intended essentially as a punishment to deter re-offending rather than as pecuniary compensation for damage. ${ }^{36}$ Under those criteria, EU corporate fines for competition law infringements were found to be "criminal":

"The probibition and the possibility of imposing a fine are enshrined in primary and secondary legislation of general application; the offence involves engaging in conduct which is generally regarded as underhand, to the detriment of the public at large, a feature which it shares with criminal offences in general and which entails a clear stigma; a fine of up to $10 \%$ of annual turnover is undoubtedly severe, and may even put an undertaking out of business; and the intention is explicitly to punish and deter with no element of compensation for damage". ${ }^{37}$

35 ECtHR, 8 June 1976, Engel and Others v.the Netherlands, $\mathbb{8} 82$, Series A no. 22.

36 Opinion of Advocate General Sharpston in Case C-272/09, P KME Germany and others v. Commission, para. 63, and the case-law cited.

37 Opinion of Advocate General Sharpston in Case C-272/09, P KME Germany and others v. Commission, para. 64; see also General Court, 14 May 1998, Case T-348/94, Enso Espanola v. Commission, paras. 55-65, and 14 September 2004, Case T-156/94, Aristain v. Commis- 


\section{$I V$. Indications of lacking suitability of corporate fines to achieve a deterrent effect}

\section{The German Monopolies Commission}

That corporate fines lack a deterrent effect has been voiced frequently: In the area of corporate fines for violations of competition rules, the German Commission on Monopolies (Monopolkommission) evaluated the case practice of the EU and Germany in 2015 and determined on this basis that it was doubtful whether even a drastic further increase in the quantum of fines would lead to a sufficiently far-reaching change in awareness with regard to the "general and special preventive objectives of the competition law sanction system...". According to the Monopolies Commission, it is "not necessarily to be expected that companies will be more strongly deterred from cartel violations by higher fines as the key sanction (general prevention)". In respect of the deterrent effect in the individual case (special prevention) the Monopolies Commission notes that "there are hardly any empirical findings regarding the deterrent effect of cartel fines ". An effective reduction of cartels could not be deduced from the number of cases, although "companies had to fear high - and tendentially rising - fines for cartel infringements in the relevant period". ${ }^{38}$ The Monopolies Commission, therefore, draws the conclusion that "the externally visible deterrent effect of official cartel prosecution will not increase significantly despite an increase in fines. Rather, there are reasons to assume that in the medium or longer term, fine-based cartel prosecution will increasingly come up against its limits, without the spread of cartels at the same time being likely to decrease in a satisfactory manner from the point of view of competition policy". ${ }^{39}$ The Monopolies Commission further argues that company fines do not have a direct effect on the acting managers, who would, therefore, not be incited to conduct themselves in conformity with the law. For example, it could be personally advantageous for sales employees to participate in a cartel without the knowledge of the management. On the other hand, individual fines on employees are rare and are, in the public perception, completely relegated to the background. ${ }^{40}$ On the basis of these empirical findings, the Monopolies Commission proposed to intensify the responsibility of the acting employees rather than to increase corporate fines. ${ }^{41}$

sion, paras. 27-30; C. Bellamy, ECHR and competition law post Menarini: An overview of EU and national case law, e-Competitions, $N^{\circ} 47946,5$ July 2012.

38 72. Special report of the Monopolies Commission, 15.10.2015, paras. 171, 175, http:// www.monopolkommission.de/images/PDF/SG/s72_volltext.pdf.

39 Ibid., para. 179.

40 Ibid., para. 183.

41 Ibid., para. $191 \mathrm{ff}$. 
2. Confirming views regarding the EU and the UK

While this view appears not to be shared by the European Commission, ${ }^{42}$ other findings support that view. It was pointed out that corporate fines are imposed "many years after an infringement was instigated, with little or no direct effect on the individual decision makers responsible" 43 and that, accordingly, corporate fines "will often prove inadequate to deter illegal behavior". ${ }^{44}$ Likewise, the EU competition law system which exclusively provides for corporate fines, has been said to contribute tittle to the prevention of competition law infringements. ${ }^{45}$ Its research of the issue led the UK's Office of Fair Trade (now Competition and Markets Authority) to the conclusion that corporate sanctions rank only fourth in terms of the deterrent effect behind criminal penalties to and disqualification of managers (which have the top ranks), publicity, and private actions. ${ }^{46}$ Corporate fines were found to lack deterrent effect because, in many cases, the company may not be in a position to control its directors effectively and the acting managers are unlikely to be deterred through this strategy as no preventative sanction is taken against them. ${ }^{47}$ More generally, it was said that they disregard how the company operates. Authors have pointed to the fact that in most cases, infringements usually involve "a handful of employees" only who are usually aware of the illegality of their conduct, and that against this background, competition law was said to be disconnected with corporate law and governance and disconcerned with the company's exposure to risk of liability and loss as a result of the illegal conduct of its directors. ${ }^{48}$

42 S. Caliskan, Individual Behaviour, Regulatory Liability, and a Company's Exposure to Risk: The Deterrent Effect of Individual Sanctions in UK Competition Law, Journal of European Competition Law E Practice, 2019, Vol. 10, No. 6, p. 386, 387.

43 A. Stephan, Disqualification Orders for Directors Involved in Cartels, Journal of European Competition Law 2(6), 2011, 529; J.C. Coffee, No Soul to Damn: No Body to Kick: An Unscandalized Inquiry into the Problem of Corporate Punishment, 79 Michigan Law Review (1980), 386, 389.

44 J.C. Cofffee, No Soul to Damn: No Body to Kick: An Unscandalized Inquiry into the Problem of Corporate Punishment. 79 Michigan Law Review (1980), 386, 389.

45 A. Khan, Rethinking Sanctions for Breaching EU Competition Law: Is Director Disqualification the Answer? 35 World Competition (2012) 77, 79; S. Caliskan, Company Liability and Competition Law: Exposure of Company to Risk of Undesirable Behaviour of Directors, Liverpool Law Review, 2019, available at https://doi.org/10.1007/s10991-019-09220-4, accessed 27 March 2020, p. 10.

46 S. Caliskan, Company Liability and Competition Law: Exposure of Company to Risk of Undesirable Beha-viour of Directors, Liverpool Law Review, 2019, available at https:// doi.org/10.1007/s10991-019-09220-4, ac-cessed 27 March 2020, p. 10.

47 S. Caliskan, Company Liability and Competition Law: Exposure of Company to Risk of Undesirable Beha-viour of Directors, Liverpool Law Review, 2019, available at https:// doi.org/10.1007/s10991-019-09220-4, ac-cessed 27 March 2020, p. 10; D. Ginsburg, and J. Wright, Antitrust Sanctions. Competition Policy International, 2010 6(2), 3, 22.

48 S. Caliskan, Company Liability and Competition Law: Exposure of Company to Risk of Undesirable Beha-viour of Directors, (2019) Liverpool Law Review, available at https:// doi.org/10.1007/s10991-019-09220-4, ac-cessed 27 March 2020, p. 10/11; Stephan, A. 2010. No Evil: Cartels and the Limits of Antitrust Compliance Programs. Company Lawyer, 


\section{Empirical studies on the prevention of misconduct of managers}

Nevertheless, statistics on corporate crime in general are said to be difficult to generate and they are subject to methodical criticism. ${ }^{49}$ To assess the effects of corporate fines it thus appears more helpful to analyse the question why managers engage in unlawful conduct. A review of the analyses on the subject shows that corporate fines do no feature as a deterrent in this context. Anecdotal epitomes of this conclusion can be found in the surprise which sentenced US white-collar criminals have expressed about their company to be fined for their misconduct ${ }^{50}$ and in the public announcement of a US whistleblower that the fine imposed as a result of his notice of misconduct to the US authorities should not be imposed on his employer (a large bank) but on the responsible managers; correspondingly the manager declined to accept the whistleblower reward due to him under US law. ${ }^{51}$ More importantly than these anecdotes, surveys on the causes for illegal conduct of managers have found that (1) such causes are diverse and include factors in the personality of the manager as well as the circumstances within the company or the industry, (2) managers who engage in unlawful conduct usually are individuals who have successfully worked for a substantial number of years for the company, and have not engaged in unlawful conduct before and (3) methods to identify the relevant managers in advance have proven uncertain and are limited by data protection rules. ${ }^{52}$ These findings lead to two conclusions: First, while circumstances encouraging or promoting unlawful conduct ("criminogenic" circumstances) can be fought, unlawful conduct can never be ruled out entirely. Second, spotting and fighting both criminogenic circumstances and managers who (may) fall for unlawful conduct, again, is a task of other (more senior) managers. Both conclusions run counter to the expectation that corporate fines deter managers from corporate crime.

\section{Recent studies on causes of unlawful conduct}

The question of the reasons for white-collar crime has long fascinated criminologists. After all, the managers who commit the crimes are individuals who do not already live on the fringes of society or in criminal milieus, or who have gone off the tracks because they could not fulfill the demands of life. Rather, they often are successful individuals in the middle of life and in the midst of society, recognised by their social envi-

31(8): 231, 236-239; Schwarcz, S.L. 2015. Excessive Corporate Risk-Taking and the Decline of Personal Blame. Emory Law Journal 65: 533, 554.

49 A. Dessecker in Momsen/Grützner, Wirtschaftsstrafrecht, 2nd ed. 2020, paras. 12 et seq.

50 E. Soltes, Why They Do It-Inside the Mind of the White-Collar Criminal, New York, 2016, 325.

51 http://www.spiegel.de/wirtschaft/unternehmen/kronzeuge-gegen-deutsche-bank-schlaegtmillionen-belohnung-aus-a-1108485.html; for more details see A. Reuter, Zeitschrift für Wirtschaftsrecht (ZIP) 2018, 2299

52 J. Hugendubel, Tätertypologien in der Wirtschaftskriminologie, Peter Lang Verlag, Frankfurt, 2016, pp. 105 et seq., 116 et seq., 167, 183 et seq. and passim. 
ronment and whose actions put not only their career but also their entire social life at stake, thus putting at risk much more than other criminals. Thus, they are peers, members of their social cohort, who get off track, and the question why a white sheep turns black may thus be felt to be particularly troublesome.

Julia Hugendubel has the great merit to have systematically reviewed all publicly available empirical studies published in German or English which were based on primary data and made between 1993 and 2013 on the causes which drive managers to infringe the law in connection with the business activities of their company (corporate crimes), be these crimes undertaken with the intent to benefit the company or with the intent to benefit the perpetrator to the detriment of the company. ${ }^{53}$ Most of these studies were undertaken to find out whether and which action companies can take to prevent illicit conduct, in particular whether it is possible to identify potential wrongdoers in advance.$^{54}$ On the basis of Hugendubel's review, the findings of these studies can be summarized as follows.

\section{Conceptual background of the empirical studies}

The empirical analyses of the causes for unlawful conduct of managers in connection with their activities for the company can be better understood on the basis of their conceptual forerunners attempting to categorize motives and personalities of the corporate wrongdoers. Sutherland has early coined the term "white-collar criminals" and set out that, contrary to other types of criminals, such criminals are respectable, and

53 J. Hugendubel, Tätertypologien in der Wirtschaftskriminologie, Peter Lang Verlag, Frankfurt, 2016, p. 49; for details of Hugendubel's selection method see see pp. 26/27 and 47 et seq. Hugendubel based her analysis on the following studies: B. Bannenberg, Korruption in Deutschland und ibre strafrechtlich Kontrolle, eine kriminologisch-strafrechtliche Analyse, 2002; W. Becker / R. Holzmann, Verhaltensanahmen betriebswirtschaftlicher Theorien und Wirtschaftskriminalität, Theoriebasierte Typisierung wirtschaftskriminellen Verhaltens, zfwu 12 (2011), 354 et seq.; K.-D. Bussmann, Business Ethics und Wirtschaftsstrafrecht, Zu einer Kriminologie des Managements, MschrKrim 86 (2003), 89 et seq.; K.-D. Bussmann, Kriminalprävention durch Business Ethics: Ursachen von Wirtschaftskriminalität und die besondere Bedeutung von Werten, zfrou 5 (2004), 35 et seq.; A. Schuchter, Perspektiven verurteilter Wirtschaftsstraftäter, Erklärungsansatz der Entstehungsgründe von Wirtschaftskriminalität und deren Prävention in Unternebmen, Dissertation St. Gallen, 2012; T. Cleff / G. Naderer / J. Volkert, Motive der Wirtschaftskriminalität, Ergebnisse einer quantitativen und qualitativen Studie, MschrKrim 94 (2011), 4 et seq.; J. M. Collins / F. L. Schmidt, Personality, integrity and white collar crime: a construct validity study, Personnel Psychology 46 (1993), 295 ff.; KPMG International, Global profiles of the fraudster, 2013; C. Krüger, Motivation und Situation - Der Wirtschaftsstraftäter im Blickpunkt der Kriminologie, in: D. Dölling / J. -M. Jehle (eds.), Täter, Taten, Opfer, 2013, 403; PricewaterhouseCoopers/Martin-LutherUniversität Halle-Wittenberg, Wirtschaftskriminalität und Unternehmenskultur, 2013; Rölfs Partner/Universität Leipzig, Der Wirtschaftsstraftäter in seinen sozialen Bezügen, 2009

54 For the hope to develop preventive strategies, A. Dessecker in C. Momsen / T. Grützner (eds.), Wirtschaftsstrafrecht, 2nd ed. 2020, para. 27. 
have a high social status in the course of their occupation. ${ }^{55}$ That outwardly white-collar criminals perfectly blend in their corporate surroundings throws up a key hurdle in identifying them, in particular in advance. As on of the recent empirical studies has word it: "One must not forget that the typical fraudster may likely remain the tenured, trusted employee. The one you may never have suspected ... right in front of your eyes, remaining unnoticed". ${ }^{56}$ In the early nineties, Wheeler broke down the personalities of white-collar criminals in the categories of "risk-seekers", "revenge-seekers" and "tax protesters". ${ }^{57} \mathrm{He}$ considers "risk-seekers" as persons driven either by "greed" or by "fear of falling", that is, the fear of not maintaining his social status and/or to suffer financial disadvantages, and against this background, they act unlawfully because they are less risk averse than most other managers. Hence, they are willing to risk their already high status and fortune by unlawful conduct. ${ }^{58}$ According to Wheeler, "revengeseekers" are persons who feel unfairly treated by their company and "tax protesters" nurse this sentiment towards the state in respect of their tax treatment. What Wheeler finds common to all categories of perpetrators is that, firstly, they apply neutralization or justification techniques to inwardly cope with their infringement of rules, ${ }^{59}$ that is, to themselves they deny the infringement, the legitimacy of the relevant rule, their responsibility, and/or the existence of victims, they bring themselves to the conviction that the victim "deserved" the damage or that the deed was justified for higher interests, or project the responsibility to others. ${ }^{60}$ Secondly, according to Wheeler, the personality of all types of perpetrators cognitively distorts their cost benefit analysis of their action ${ }^{61}$.

In contrast, Becker/Holzmann ${ }^{62}$ base their conceptual categorization of corporate wrongdoers and the causes for their action on rational management theory, notably on

55 J. Hugendubel, Tätertypologien in der Wirtschaftskriminologie, Peter Lang Verlag, Frankfurt, 2016, p. 49/50; E.H. Sutherland, White Collar Crime, 2nd ed., New York, 1961, p. 9.

56 KPMG International, Global Profiles of the Fraudster, 2013, p. 26.

57 S. Wheeler in: K. Schlegel / D. Weisburd (eds.), White-Collar-Crime Reconsidered, 1998, p. 108- 118; J. Hugendubel, Tätertypologien in der Wirtschaftskriminologie, Peter Lang Verlag, Frankfurt, 2016, p. 51/52.

58 S. Wheeler in: K. Schlegel / D. Weisburd (eds.), White-Collar-Crime Reconsidered, 1998, p. 108- 118; J. Hugendubel, Tätertypologien in der Wirtschaftskriminologie, Peter Lang Verlag, Frankfurt, 2016, p. 51/52.

59 S. Wheeler in: K. Schlegel / D. Weisburd (eds.), White-Collar-Crime Reconsidered, 1998, p. 108- 118; J. Hugendubel, Tätertypologien in der Wirtschaftskriminologie, Peter Lang Verlag, Frankfurt, 2016, p. 52.

60 S.Wheeler in: K. Schlegel / D. Weisburd (eds.), White-Collar-Crime Reconsidered, 1998, p. 108- 118; J. Hugendubel, Tätertypologien in der Wirtschaftskriminologie, Peter Lang Verlag, Frankfurt, 2016, p. 52, note 169, referring to G. Sykes / D. Matza, Techniques of Neutralization: A Theory of Delinquency, American Sociological Review 22 (1957), 664, 667 et seq., and Kunz, Kriminologie, 4th ed. 2004, p. 150.

61 S. Wheeler in: K. Schlegel / D. Weisburd (eds.), White-Collar-Crime Reconsidered, 1998, p. 108, 110, 115; J. Hugendubel, Tätertypologien in der Wirtschaftskriminologie, Peter Lang Verlag, Frankfurt, 2016, p. 51.

62 W. Becker/R. Holzmann, Verhaltensannahmen betriebswirtschaftlicher Theorien und Wirtschaftskriminalität, Theoriebasierte Typisierung wirtschaftskriminellen Verhaltens, zfwu 
the principal agent theory which stresses that the company ${ }^{63}$ delegates decision-making powers to managers and that managers avail more information on the company's activities than the shareholders ("asymmetrical distribution of information") ${ }^{64}$. Criminal managers abuse their better information to their personal benefit (embezzlement, theft, corruption; "classic agent perpetrators"), or in the putative interest of the company with the type of the "guided agent perpetrator" acting more extrinsically motivated by company targets and the alignment of such targets with his personal financial goals and the "steward perpetrator" type acting more intrinsically motivated for enjoyment of his work and the success associated therewith for his company. ${ }^{65}$

3. Empirical studies: Who commits corporate crimes?

a) No significant changes between wrongs against or for the company

To begin with, in their analysis of causes of corporate crime, none of the studies was able to identify significant differences between the personalities of wrongdoers who act to the detriment of the company (for example by embezzlement of money) and wrongdoers acting in the putative interest of the company (for example cartelists or bribers). ${ }^{66}$ This distinction is blurred anyway because wrongdoers acting in what they believe to be the interest of the company (putative interest) usually have an indirect personal interest associated with the deed. Corresponding to this empirical lack of distinction in the personalities of wrongdoers for and against the interest of the company, the measures which the studies recommend to prevent unlawful conduct do not distinguish between these two types of conduct ${ }^{67}$.

12 (2011), 354, 377, 379; J. Hugendubel, Tätertypologien in der Wirtschaftskriminologie, Peter Lang Verlag, Frankfurt, 2016, p. 51.

63 It shall be left open here who in the present context, from a legal perspective, is the "company".

64 J. Hugendubel, Tätertypologien in der Wirtschaftskriminologie, Peter Lang Verlag, Frankfurt, 2016, p. 53.

65 J. Hugendubel, Tätertypologien in der Wirtschaftskriminologie, Peter Lang Verlag, Frankfurt, 2016, p. 53/54; W. Becker /R. Holzmann, Verhaltensannahmen betriebswirtschaftlicher Theorien und Wirtschaftskriminalität, Theoriebasierte Typisierung wirtschaftskriminellen Verhaltens, Zeitschrift für Wirtschafts- und Untenehmensethik, 12 (2011), 354,365 et seq.

66 J. Hugendubel, Tätertypologien in der Wirtschaftskriminologie, Peter Lang Verlag, Frankfurt, 2016, p. 100; H. Theile, Unternehmensrichtlinien aus kriminologischer Sicht, in Rotsch (ed.), Criminal Compliance, Handbuch 2015, 1219, 1221.

67 J. Hugendubel, Tätertypologien in der Wirtschaftskriminologie, Peter Lang Verlag, Frankfurt, 2016, p. 100; Hans Theile, Unternehmensrichtlinien aus kriminologischer Sicht, in T. Rotsch (ed.), Criminal Compliance, Handbuch 2015, 1219, 1221. 


\section{b) Basic characteristics}

All empirical studies come to the conclusion that most white-collar criminals are male, have successfully worked for their company for at least couple of years before they engage in criminal conduct, are usually between 35 and 60 years old (thereby confirming Sutherland's finding that white-collar wrongdoers are "latecomers to crime" ${ }^{\prime 8}$ ), hold senior positions in the company, typically act in cooperation with other managers, are well-trained, generally share common views on social and legal standards, but make exceptions for themselves or their level of seniority, are hedonistic and financially ambitious. ${ }^{69}$ In her study on perpetrators of corporate corruption, Bannenberg remarks that the relevant criminals are inconspicuous. ${ }^{70}$

\section{c) Motives and personalities}

Collins/Schmidt have found substantial measurable differences in the personalities of white-collar criminals and law-abiding managers in that the earlier ones tend to irresponsibility, unreliability, disregard for legal and social rules and a willingness to take risks ("risk takers"). ${ }^{71}$ Blickle/Schlegel/Fassbender et al. have expanded the Collins/ Schmidt study and found a significantly increased degree of hedonism, narcissism and lack of self-restraint in the personalities of white-collar criminals compared to lawabiding managers.

KPMG has run various studies which come to the conclusion that it is a combination of (1) the opportunity for misconduct, (2) the motivation/personality of the wrongdoer and (3) the availability of inward neutralization or justification of the wrongdoing. ${ }^{72}$ The statistically most prominent motivations identified by KPMG are financial advantages (need for financing an extravagant life style, pecuniary trouble, greed, fear of losing social status); furthermore KPMG found that many wrongdoers are characterized by a feeling of superiority and, similar to the findings of Collins/ Schmidt, that the rules for normal employees do not apply to managers of their level of seniority. ${ }^{73}$ KPMG also noted an increasing trend of an involvement of IT in white-

68 Quoted after H. Schneider, Das Leipziger Verlaufsmodell wirtschaftskriminellen Handelns, Nene Zeitschrift für Strafrecht 27 (2007), 555, 557/558.

69 J. Hugendubel, Tätertypologien in der Wirtschaftskriminologie, Peter Lang Verlag, Frankfurt, 2016, p. 60, 63/64, 66. 68, 78 .

70 B. Bannenberg, Korruption in Deutschland und ibre strafrechtlich Kontrolle, eine kriminologisch-strafrechtliche Analyse, Neuwied/Kriftel, 2002, p. 216 f., 347.

71 J. Hugendubel, Tätertypologien in der Wirtschaftskriminologie, Peter Lang Verlag, Frankfurt, 2016, p. 56, 58, 83; J. M. Collins / F. L. Schmidt, Personality, integrity and white collar crime: a construct validity study, Personnel Psychology 46 (1993), 295, 297, 308.

72 KPMG International, Global profiles of the fraudster, 2013, p. 6 et seq.; J. Hugendubel, Tätertypologien in der Wirtschaftskriminologie, Peter Lang Verlag, Frankfurt, 2016, p. 64.

73 KPMG International, Global profiles of the fraudster, 2013, p. 6 et seq.; J. Hugendubel, Tätertypologien in der Wirtschaftskriminologie, Peter Lang Verlag, Frankfurt, 2016, p. 64. 
collar crime ${ }^{74}$ which appears to be in line with both the mentioned factor "opportunity" and the wrongdoer's feeling of superiority.

The empirical study of Rölfs Partner/Schneider finds that corporate wrongdoers tend to a wrongful cost benefit analysis of their acts, in particular underestimate the risk of discovery and the sanctions $s^{75}$. The study categorizes wrongdoers in four risk types, that is: (1) "Wrongdoers with a corporate crime burden syndrome", who seek and grasp opportunities, in particular in situations with a lesser degree of control, often form part of subculture groups in their company and have large financial needs to cater for an "earning and burning money" lifestyle; (2) "wrongdoers out of a crisis" who live within the social norms, have often climbed up the corporate hierarchy and the social ladder but are unhinged by a crisis which leads to unusual pressure; unlike "type" (1), the study considers these wrongdoers unsually not to avail of inward neutralization or justification methods and to have a strong tendency to confess once discovered; (3) "dependents", that is, wrongdoers who, like "type (1)" form part of subculture groups in their company, grasp, but do not seek, opportunities, are followers rather than leaders in such groups, and fear pressure if they do not play along; and (4) the "inconspicuous", that is, wrongdoers who usually comply with the rules, but have relations to other corporate wrongdoers and act wrongfully because of more singular opportunity. ${ }^{76}$

Differing categories of wrongdoers are suggested by the empirical study of Cleff/ Naderer/Volkert ${ }^{77}$ who distinguish between the "egocentric visionary", the "frustrated visionary", the "narcist visionary", the "dependent type" and the "naive type". The characteristics of these "types" comprise the characteristics of wrongdoers of the other studies, albeit somewhat differently grouped. That study also confirms the finding of the other studies that corporate wrongdoers are often successful managers and feature both ambition and persistence. ${ }^{78}$ Additionally, Cleff/Naderer/Volkert suggest a certain correlation between wrongdoing on the one hand and the relevant industry on the other hand: Industries with high transaction volumes such as financing or real estate are

74 KPMG International, Global profiles of the fraudster, 2013, p. 2.; J. Hugendubel, Tätertypologien in der Wirtschaftskriminologie, Peter Lang Verlag, Frankfurt, 2016, p. 64.

75 J. Hugendubel, Tätertypologien in der Wirtschaftskriminologie, Peter Lang Verlag, Frankfurt, 2016, p. 69, referring to Rölfs Partner/Universität Leipzig, Der Wirtschaftsstraftäter in seinen sozialen Bezügen,, 2009, p. 10.

76 J. Hugendubel, Tätertypologien in der Wirtschaftskriminologie, Peter Lang Verlag, Frankfurt, 2016, p. 69, referring to Rölfs Partner/Universität Leipzig, Der Wirtschaftsstraftäter in seinen sozialen Bezügen, 2009, p. 18/19.

77 J. Hugendubel, Tätertypologien in der Wirtschaftskriminologie, Peter Lang Verlag, Frankfurt, 2016, p. 75, referring to T. Cleff / G. Naderer / J. Volker, Motive der Wirtschaftskriminalität, MschKrim 94 (2011), 4, 5 et seq.

78 J. Hugendubel, Tätertypologien in der Wirtschaftskriminologie, Peter Lang Verlag, Frankfurt, 2016, p. 72, referring to T. Cleff / G. Naderer / J. Volker, Motive der Wirtschaftskriminalität, MschKrim 94 (2011), 4, 9. 
said to be particularly jeopardized. An increased risk is also found in overly complex company structures as well as in obsolete and rigid company structures. ${ }^{79}$

Hugendubel's overview of empirical studies ends with Schlegel's comparative analysis of the values of sentenced delinquent managers and non-delinquent managers. Schlegel found delinquent managers to be more narcissistic and to attach significantly higher appreciation and importance to values such as "power", "achievement", "hedonism", “conformity", "security" and "benevolence” than non-delinquent managers. However, not all findings confirm the expectation: Schlegel noted a stronger "inclination" to unlawful conduct amongst the non-delinquent managers than amongst the delinquent managers, but on the other hand pointed out that delinquent managers more strongly tended to answer questions guided by the socially desirable. ${ }^{80}$

\section{Preventive measures}

While all empirical studies find a bundle of characteristics in, and arrive at similar typologies of, white-collar criminals, these characteristics and categories are diverse and, despite substantial overlaps, incongruent. Furthermore, these characteristics may result in unlawful conduct only where appropriate opportunities or other situational circumstances arise ${ }^{81}$. Given the diversity of characteristics, typologies and circumstances, it does not come as a surprise that preventive measures have differing effects on potential criminals, and that the preventive measures which the empirical studies suggest are diverse so as to provide broad cover. ${ }^{82}$ There may even be instances which have a crime preventing effect on some managers but a criminogeneous effect on others. ${ }^{83}$ Nevertheless, the catalogues of measures often resemble each other and are comprised of ${ }^{84}$

79 J. Hugendubel, Tätertypologien in der Wirtschaftskriminologie, Peter Lang Verlag, Frankfurt, 2016, p. 72, referring to T. Cleff / G. Naderer / J. Volker, Wirtschaftskriminalität, 2009, p. 30.

80 J. Hugendubel, Tätertypologien in der Wirtschaftskriminologie, Peter Lang Verlag, Frankfurt, 2016, p. 69, referring to A. Schlegel, Wertehaltung inhaftierter Wirtschaftsdelinquenten, in: A. Schlegel (ed.), Wirtschaftskriminalität und Werte, Nordhausen 2003, 113, 114 et seq., 181.

81 J. Hugendubel, Tätertypologien in der Wirtschaftskriminologie, Peter Lang Verlag, Frankfurt, 2016, p.163/164.

82 J. Hugendubel, Tätertypologien in der Wirtschaftskriminologie, Peter Lang Verlag, Frankfurt, 2016, p. 71 and 76/77, referring to Rölfs Partner/Universität Leipzig, Der Wirtschaftsstraftäter in seinen sozialen Bezügen, 2009, p. 21/22, and to T. Cleff / G. Naderer / J. Volker, Motive der Wirtschaftskriminalität, Monatsschrift für Kriminologie und Strafrechtsreform 94 (2011), 4, 12 et seq., respectively

83 J. Hugendubel, Tätertypologien in der Wirtschaftskriminologie, Peter Lang Verlag, Frankfurt, 2016, p. 162, referring to P. Krüger in Dölling/Jehle (ed.), Täter, Taten, Opfer, 2013, p. 403, 410 et seq.

84 J. Hugendubel, Tätertypologien in der Wirtschaftskriminologie, Peter Lang Verlag, Frankfurt, 2016, p. 55, 57, 62, 63, 65, 67, 68, 70, 71, 72, 76, 79 and 115; B. Bannenberg, Korruption in Deutschland und ibre strafrechtlich Kontrolle, eine kriminologisch-strafrechtliche Analyse, Neuwied/Kriftel, 2002, p. 472/473, 478. 
(1) Personality tests before hiring a manager,

(2) regular personality tests, in particular in critical areas,

(3) request for regular presentation of criminal record certificates issued by the police (persönliches Führungszengnis),

(4) removal of suspect employes to other departments or regular rotations,

(5) clear governance rules, communicated with an "ethical leadership" approach and a "tone from the top" 85 : Soltes' recent compilation and analysis of studies on US corporate crime cases demonstrates the importance of that factor: It seems that corporate crime often develops in "subcultures" within companies and it appears plausible that such subcultures can thrive better where they are connived at by the chief executives; ${ }^{86}$

(6) regular information,

(7) regular trainings to increase sensibility,

(8) installation of effective internal processes (four eyes principle etc.),

(9) regular controls,

(10) consequent enforcement, including consequent and adequate reaction in case of non-compliance, notably investigations and corresponding reaction,

(11) whistleblower procedures and hotlines,

(12) central departments to install and monitor the above compliance measures.

5. Summary of findings of the empirical studies: Limits to prevention

All empirical studies find a bundle of characteristics in white-collar criminals. The diversity, including the interaction between personalities and situational circumstances renders it impossible to prevent corporate crime entirely. This particularly applies to personality tests aiming at the identification of white-collar criminals in advance, be this by means of the above typology or otherwise. To begin with, many of the characteristics identified by the studies can also be found in successful managers who, however, never become delinquent ${ }^{87}$. Furthermore, there is the mentioned multiple interaction between personality and situational circumstances, such as personal crises, arising opportunity, samples of misconduct in the company which others follow, promotion of the manager to a position making the misconduct possible, etc. ${ }^{88}$ Hence, a forecast

85 PricewaterhouseCoopers / Martin-Luther-Universität Halle-Wittenberg, Wirtschftskriminalität und Unternehmenskultur, 2013, p. 75; http://www.pwc.de/risiko-management / wikri-2013.jhtml; quoted after J. Hugendubel, Tätertypologien in der Wirtschaftskriminologie, Peter Lang Verlag, Frankfurt, 2016, p. 67/68.

86 E. Soltes, Why They Do It- Inside the Mind of the White-Collar Criminal, New York, 2016, 115 et seq, 175 et seq,, 201 et seq,, 224 et seq,. 257 et seq,

87 J. Hugendubel, Tätertypologien in der Wirtschaftskriminologie, Peter Lang Verlag, Frankfurt, 2016, p. 161.

88 J. Hugendubel, Tätertypologien in der Wirtschaftskriminologie, Peter Lang Verlag, Frankfurt, 2016, p. 161/162. 
that a certain manager will violate the rules in the nearer or farther future is impossible. ${ }^{89}$

For purposes of this article, these findings can be summarized as follows: (1) Corporate crime is caused by interaction between both personalities and circumstances, (2) it is impossible to identify future perpetrators in advance and (3) while it is possible to increase compliance by preventive measures, infringements can never be ruled out.

By the same token, none of the empirical studies provides any indication that perpetrators take into account the consequences of their conduct for the company when deciding whether or not to break the law. On the contrary, the empirical studies show that white-collar criminals generally apply a distorted cost-benefit analysis, i.e. underestimate the risk of detection and its consequences. The threat that their conduct will be punished does not stop them from their actions. It seems plausible that this is all truer when the company, not the perpetator, is sanctioned, i.e. third parties. ${ }^{90}$ This, in turn, fits in with the Monopolies Commission's findings as already outlined in Chapter IV 1 above: The Monopolies Commission emphasizes that that corporate fines do not have a direct effect on the employees, who would, therefore, not be incited to comply with the law. All of this leads to the following conclusion: Corporate sanctions are, not only for legal reasons unsuitable to prevent white-collar crime, but also from an empirical point of view.

6. Hugendubel's criticism to the studies and the impact of such criticism on the present findings

It is worthy of note that Hugendubel, on the basis of her review of the studies, criticises them to suffer from certain methodogical' flaws. She points out that the studies fail to set out clear structures necessary for empirical analyses, that the selected interviewees are not representative, that most of the studies fail to apply their interviews to a non-delinquent peer group and to neglect the situational impacts, that the answers of the interviewees were not controlled although the interviewed managers were usually senior, well-educated and thus able to guide their answers, and that the results of the studies often were not replicable. ${ }^{91}$ Hugendubel then goes on to stress the complex

89 J. Hugendubel, Tätertypologien in der Wirtschaftskriminologie, Peter Lang Verlag, Frankfurt, 2016, p. 162, referring, inter alia, to K.-D. Bussmann, Kriminalprävention durch Business Ethics, Zeitschrift für Wirtschafts- und Unternebmenetbik, 5 (2004), 35, 41; A. Schuchter, Risk, Frau Compliance (ZRFC) 2010, 80, 83; A. Schuchter, Perspektiven verurteilter Wirtschaftsstraftäter, 2012, p. 80.

90 Cf. E. Soltes, Why They Do It-Inside the Mind of the White-Collar Criminal, New York, 2016, p. 325: "And, ironically, fines levied on offending firms are ultimately paid by the shareholders rather than by the executives or employees who actually engaged in the misconduct. Without specter of the full justice system hanging over them as is the case with individual defendants, labeling firms as criminal often has surprisingly weak, or even misdirected, effects".

91 J. Hugendubel, Tätertypologien in der Wirtschaftskriminologie, Peter Lang Verlag, Frankfurt, 2016, p. 153 and 122 et seq. For a similar methodological ciriticism of profiling of white col-

EuCLR Vol. 10, 3/2020 
character of human behaviour and its causes, the lacking possibility in advance to distinguish potentially delinquent managers from law-abiding managers, and the similarity of personalities of delinquent and non-delinquent managers. On that basis, she concludes that it is neither possible to deduce forecasts on future misconduct from personal biographies of managers, nor from personality tests. ${ }^{92}$

In addition, personality tests may have strong but unjustified negative labelling effects on managers in respect of whom the test results indicate a delinquency potential. Taken together with their lacking reliability, personality tests may thus violate personal data protection regulations as well as fundamental rights of the managers, ${ }^{93}$ Hugendubel's key conclusions are that (i) in view of the described findings, situational structures and circumstances of the company are the key cause for white-collar crime, (ii) preventive measures cannot be personality-based but must be of a general nature with a clear communication of the values of the company to play an essential role, and (iii) such communication must be geared to the specific structures and circumstances of the company. ${ }^{94}$

It is doubtful whether or not conclusion (i) holds true: After all, there are many managers who do not become delinquent in structures and circumstances in which some managers do. Hence, while situational structures and circumstances of the company are likely to play a role (such as "the tone from the top", see Chapter V 4 (5) above), this does not refute the impact of the differences in the personalities of delinquent and non-delinquent managers. In addition, the relevant "situational structures and circumstances of the company" are the result of the action (or non-action) of the management itself and can be structured taking into account the relevant setting. What is more important for assessing the empirical background of corporate fines, is, however, that Hugendubel's conclusions (ii) and (iii) (although based on her criticism over the empirical studies) confirm the findings set forth in Chapter V 5 above: (1) Corporate crime is caused by interaction between both personalities and circumstances, (2) it is impossible to identify future perpetrators in advance and (3) while it is possible to increase compliance by preventive measures, infringements can never be ruled out.

lar criminals on the basis of personality structures, L. Ragatz / W. Freemouw, A Critical Examination of Research on the Psychological Profiles of White-Collar Criminals, Journal of Forensic Psychology Practice 10 (2010), 373, 383, 393, 398.

92 J. Hugendubel, Tätertypologien in der Wirtschaftskriminologie, Peter Lang Verlag, Frankfurt, 2016, p. 153 and 168.

93 J. Hugendubel, Tätertypologien in der Wirtschaftskriminologie, Peter Lang Verlag, Frankfurt, 2016, p. 153 and 183 et seq.

94 J. Hugendubel, Tätertypologien in der Wirtschaftskriminologie, Peter Lang Verlag, Frankfurt, 2016, p. 153 and 168. 


\section{Profit orientation of companies as "criminogenic factor" for which the shareholders are responsible?}

Put differently, infringements could be entirely ruled out only if the company discontinues its operations, thereby removing all opportunities for misconduct. However, the law does not require companies to discontinue their business. Discontinuation of lawful businesses to extinguish corporate crime would remove the economic basis of our society (including the basis of living of law enforcers). Hence, it is not an option.

While some of the studies expressly set out that, in addition to the personality of the wrongdoers, there are situational causes for white-collar crime, the above list shows that studies place the emphasis of their suggestions for prevention on measures geared at the personality of the wrongdoers. This has been criticized as an attempt to divert from the company's "own" responsibility. The more a personality-based analysis of white-collar crime emphasizes that wrongdoers are inconspicuous, and thus hard to identify in advance, the further "the company" is relieved from blame $e^{95}$, and the "persons really responsible are exculpated" 96 .

No question, the empirical studies have confirmed that white-collar crime is a phenomenon with many, not only one cause, that opportunity and surroundings, in short, the "situation" in which the relevant rules were infringed, are a possible causes for the infringement ${ }^{97}$, and thus empirically underpinned the commonplaces that "open doors tempt saints" and "opportunity makes thieves". As regards infringements by managers in the putative interest of the company, the general profit orientation of companies in a market economy appear to lend an even broader fundamental for such criticism. The expectation that the company be successful and make money is instilled in all managers top down from shareholders, boards and senior management all the way throughout the company.

However, even if one were, from an empirical point of view, to find that the circumstantial setting of the deed, including pervasive profit expectations, contribute to the causation of white-collar crime and would thus have to consider them as "criminogeneous", such empirical considerations would be irrelevant in the present context of corporate fines:

First, the purposes of the fines must be taken into account. As set out in Chapter II above, fines encroach upon fundamental rights of shareholders and must thus be justifiable by their suitability to achieve their purpose. In the already quoted words of the ECJ, competition rules are "to punish anticompetitive behaviour on the part of under-

95 R. Hefendehl, Corporate Governance und Business Ethics: Scheinberuhigung oder Alternativen bei der Bekämpfung von Wirtschaftskriminalität, Juristenzeitung 2006, 119, 124; J. Hugendubel, Tätertypologien in der Wirtschaftskriminologie, Peter Lang Verlag, Frankfurt, 2016, p. 98.

96 J. Hugendubel, Tätertypologien in der Wirtschaftskriminologie, Peter Lang Verlag, Frankfurt, 2016, p. 98; H. Croall, Understanding white collar crime, Buckingham, 2001, p. 83.

97 KPMG International, Global profiles of the fraudster, 2013, p. 6 et seq.; J. Hugendubel, Tätertypologien in der Wirtschaftskriminologie, Peter Lang Verlag, Frankfurt, 2016, p. 64, 69, $159-164$. 
takings and to deter them from engaging in such conduct" ${ }^{\prime 98}$. However, as set out in Chapter I, "the company" as such is but a pile of paper kept by the relevant company register and can be "blamed", "punished" or "influenced" as little as the waves of the Hellespont could by Xerxes. These punitive purposes can only be achieved in human individuals.

Second, the vast majority of companies is not criminal, and investing in companies with a profit target is legal. Again, only if the company ceases operations, violations can be completely ruled out. However, the legal system does neither require companies to cease operations, nor require invesors to cease investing in companies; rather, the legal system presupposes entrepreneurial activity, protects it and finances the community to a large extent from taxes on the profits that companies generate. If one were to classify the lawful participation in a company and its profits as so "criminogenic" that they justify corporate sanctions in the event of a breach of law by managers, then in the event of a traffic offence (think of sports cars) car dealers, car manufacturers and (in view of motor vehicle taxes) the tax authorities would also have to be sanctioned as beneficiaries of the car. This would, however, fail to recognise (1) that selling a car is just as legal as investing in a company and (2) that the driver of the car, just like the manager, is a grown-up, responsible person mastering its conduct.

Third, the described "situational conditions which make thieves" are man-made as well, or, put more accurately: "manager-made" as well. Hence, if one is dissatisfied with an analysis of causes for white-collar crime confined to a personality-based approach, such dissatisfaction would not warrant corporate fines. At most, such dissatisfaction may necessitate and warrant a search for other human individuals in which the described punitive purposes can be achieved. However, such search for responsible human individuals has to take into account the way in which the legal order, notably corporate law, allocates duties, rights and responsibility within the company. Shareholders can thus be economically burdened only where they have violated duties imposed on them by corporate law.

\section{Individual versus corporate sanctions and the economic theory of law}

1. Considerations of the economic theory of law

In contrast, the economic theory of criminal law ${ }^{99}$ has found corporate liability to play an important role in deterring corporate crime. Although that theory is, to begin with,

98 ECJ, 14 March 2019, Case C-724/17, Skanska, para. 45.

99 For an overview, P. Polidori / D. Teobaldelli, Corporate Criminal Liability, in: A. Marciano, G.B. Ramello (eds.), Encyclopedia of Law and Economics, 2016, DOI 10.1007/978-1-4614-7883-6_701-1; from the voluminous litterature see, for example, J. Arlen and R. Krakman, Controlling corporate misconduct: an analysis of corporate liability regimes, New York University Law Review, 1997, 72 (4), 687 et seq.; A. O. Sykes, The Boundaries of VicariousLiability: An Economic Analysis of the Scope of Employment Rule and Related LegalDoctrines, 101 Harv. L. Rev. 563, 579-81 (1988). 
"neutral" between individual and corporate liability, corporate crime is held often to generate large social costs. Hence, individual liability was expressed not to suffice because employees cannot pay fines commensurate to such social costs. Furthermore, imprisonment of individuals was found to increase deterrence, but to be insufficient because (a) even life imprisonment was considered unsatisfactory given that corporate wrongdoers tend to be relatively old, (b) imposing long prison sentences for nonviolent crimes, such as corporate crimes, may not be possible because this reduces the room for appropriate sanctions for violent criminal offences, and (c) imprisonment again entails very large costs to society. ${ }^{100}$ Furthermore, it was said that there is a low probability of sanction given the complexity of corporate crime which often involve many individuals and determining those responsible is often difficult. Pursuant to the economic theory of law, the cost and low probability of enforcement calls for high corporate sanctions. By the same token, it was said that optimal deterrence needs to take into account that the company has a comparative advantage in the collection of information relative to the state. Hence, to optimize deterence, it was argued that the state has not only to invest in enforcement and to impose the optimal sanctions on individuals, but by corporate sanctions to incentivize the company to engage in prevention and policing measures. ${ }^{101}$

\section{Impact of these considerations}

It is beyond the scope of this article to discuss these considerations. However, convincing or unconvincing, these considerations call into question neither the proposition that corporate sanctions are an unproportionate restriction of shareholders' fundamental rights (see Chapter II), nor this article's finding that corporate fines do not have a deterrent effect on the acting managers (Chapters IV and V):

In respect of the earlier proposition, to begin with, the proporationality must be determined in respect of the legislative purposes which the legislator actually pursues, not in respect of potential other purposes. Hence, the proportionality test has to be geared to the purpose of EU corporate fines as set forth in Chapter III 2. More importantly: Without doubt, imposing corporate fines is easier, less costly, and benefits public treasuries more, than law enforcement against the repsonsibe individuals. However, this does not justify an unproportionate restriction of fundamental rights of shareholders. This holds true because fundamental rights are enshrined in the law, including EU law, irrespective of cost and budgetary considerations. Pointedly, sanctioning innocent bystanders (for example the next of kin [Sippembaft] in case of misconduct is certainly less costly than enforcement against the culprits just as the execution of a death sen-

100 P. Polidori / D. Teobaldelli, Corporate Criminal Liability, in: A. Marciano, G.B. Ramello (eds.), Encyclopedia of Law and Economics, 2016, DOI 10.1007/978-1-4614-7883-6_701-1

101 Ibid; J. Arlen and R. Krakman, Controlling corporate misconduct: an analysis of corporate liability regimes, New York University Law Review, 1997, 72 (4), 687 et seq.; J. Arlen, Corporate criminal liability. Theory and Evidence, in: A. Harel, K. N. Hylton (eds.), Research Handbook on the Economics of Criminal law, section 7, 2012. 
tence may be less costly than years of imprisonment. Yet, such sanctions remain unlawful despite their low cost. However, even one applies economic considerations, one has to take into account the cost to society if the state were allowed to impose sanctions without due regard to fundamental rights. Society would give up the rule of law which would undermine its entire fabric. That cost is unmeasurable.

Likewise, the considerations of the economic theory of law do not impact the above finding (Chapter V 5) that corporate sanctions are, from an empirical point of view, unsuitable to prevent white-collar crime. Empirical findings cannot be refuted by a conceptual approach. To the extent, however, the economic theory of law were to recommend corporate sanctions on the basis of the assumption that such sanctions would also have a deterrent effect on managers, the above findings remove that basis.

\section{Conclusions and consequences}

\section{Conclusions}

As set forth in Chapter III 2, under TFEU art. 103 (2) lit. a), art. 23 of Regulation (EC) No. 1/2003 corporate fines are to ensure "[c]ompliance with Articles [101] and [102] of the Treaty and the fulfilment of the obligations imposed on undertakings and associations of undertakings under this Regulation". However, the findings of the empirical studies show that managers' law infringements are driven by factors detached from corporate fines. The studies thus indicate that corporate fines fail to achieve their purpose and do not contribute to the prevention of law infringements by managers. Put conversely, none of the empirical studies indicates, let alone demonstrates, that corporate fines are suitable to achieve or contribute to their purpose.

On the strength of these findings, one might already conclude that corporate fines, "manifestly inappropriate or unsuitable" to achieve their legislative object, fail the ECJ's proportionality test mentioned. However, in connection with complex or prognostic decisions, the ECJ grants the EU institutions a wide margin of discretion in the implementation of Union $\mathrm{law}^{102}$. In this context, the ECJ refers to the need to assess politically, economically or socially complex situations, ${ }^{103}$ or to the prognostic character of decisions. ${ }^{104}$ Accordingly, the only measures objected to are those which are

102 ECJ, 17 October 1995, Case C-44/94, Fishermen`s Organisations, paras. 56 et seq.; Wollenschläger in von der Groeben/Schwarze/Hatje (ed.), Europäisches Unionsrecht, 7th ed., Art. 15 ChFR, para. 42.

103 ECJ, 27 June 1989, Case 113/88, Leukhardt, para. 20; ECJ, Joined Cases C-154/04 and C-155/04, Alliance for Natural Health para. 52; ECJ, 12 December 2006, Germany v. Commission and Parliament, Case C-380/03, para. 145; ECJ, 26 September 2014, Case T629/13, Molda AG, para. 61.

104 ECJ, 5 October 1994, Case 280/93, Germany v. Council, para. 90. 
"manifestly inappropriate"105. If this is not the case, it is irrelevant "whether the measure enacted by the legislator is the only possible or the best possible measure". ${ }^{106}$ Furthermore, the Union legislator's forecast decisions, which are necessarily subject to uncertainty, are only criticised "if they appear to be manifestly erroneous with regard to the knowledge available to the Union legislator at the time the regulation was enacted". ${ }^{107}$ Manifest errors, however, require correction. ${ }^{108}$

Yet, the described empirical findings are fairly aligned and the Commission has almost had 60 years of practice. Hence, it is not a foregone conclusion that assessing the effect of corporate fines on managers really constitutes a "politically, economically or socially complex" or a "prognostic" decision. Given the methodical criticism regarding the studies (see Chapter V 6), one may, from an empirical point of view, require more systematic empirical research. However, it is difficult to imagine that empirial research would refute the findings of Chapter V, namely that (1) corporate crime is caused by interaction between both personalities and circumstances, (2) it is impossible to identify future perpetrators in advance, (3) while it is possible to increase compliance by preventive measures, infringements can never be ruled out, and (4) hence, the shareholders are not in a position, by selection or direction of the managers, to rule out law infringements by the management. These empirical findings appear plausible, and that the Commission's fines have been steadily increasing over the years is an additional indicator that they lack effect, no matter how drastic they are. Hence, even without such additional research the described studies do not only corroborate the concerns, referred to in Chapter II as regards the deterrent effect of corporate fines. They also indicate the factual failure of the concept economically to hit sharebolders so as to produce effects on managers. Hence, the legal finding of Chapter II is confirmed: As corporate fines hit the wrong, they are even more despotic than Xerxes' flogging of waves which feel - unlike shareholders - no pain.

105 ECJ, 11 July 1989, Case 265/87, Schräder, para. 22; ECJ, 13 November 1990, Case C-331/ 88, FEDESA et al., paras. 14 et seq; ECJ, 5 October 1994, Case 280/93, Germany v. Commission, para. 90; ECJ, 13 December 1994, Case C-306/93, SMW Winzersekt/Land Rheinland-Pfalz, paras. 21, 27; ECJ, 12 May 2005, Case C-347/03, Regione autonoma Friuli-Venezia Giulia and ERSA, para. 131; ECJ, 12 July 2001, Case C-189/01, Jippes et al., para. 82; ECJ, 12 January 2006, Case C-504/04, Agrarproduktion Staebelow, para. 36.

106 ECJ, 12 July 2001, Case C-189/01, Jippes et al., para. 83; F. Wollenschläger in von der Groeben/Schwarze/Hatje (ed.), Europäisches Unionsrecht, 7th ed., Art. 15 ChFR, para. 43.

107 ECJ, 5 October 1994, Case 280/93, Germany v. Commission, para. 90; ECJ, 21 February 1990, Joined cases C-267/88 to C-285/88, Wuidart et al., para. 14; ECJ, 12 July 2001, Case C-189/01, Jippes et al., para. 84; ECJ, 12 January 2006, Case C-504/04, Agrarproduktion Staebelow, para. 38.

108 ECJ, 12 January 2006, Case C-504/04, Agrarproduktion Staebelow, para. 40; F. Wollenschläger in von der Groeben/Schwarze/Hatje (ed.), Europäisches Unionsrecht, 7th ed., Art. 15 ChFR, para. 43. 


\section{Consequences}

If, however, corporate fines (that is, fines on undertakings) run afoul of shareholders' rights, what is left from TFEU art. 103 (2) lit. a), art. 23 of Regulation (EC) No. $1 / 2003$ ? Their application should, indeed, be substantially modified as follows so as to stop "flogging the wrong":

(1) Enforcement should be focused on the responsible managers. Since EU law does not allow fines against managers, such fines should be delegated to the member states. Where shareholders have caused the company to engage illicit conduct, the relevant managers of the shareholders should be included in such enforcement focus. Where such shareholders are natural persons, they have been able to "control" the company's conduct and are thus an undertaking themselves and can be fined directly.

(2) Corporate fines should be reduced to a confiscation of profits; these profits should be assessed realistically and not constitute hidden punishment.

Enforcement as described in items 1 and 2 act as effective deterrent to management and thus suffice. A further proposal shall be added:

It has rightly been said that fines running into millions are a feature of "modern competition law" which has been "inconceivable" when the Treaties were originally signed. Hence, at the very least, fine amounts should be substantially reduced. Furthermore, EU law should expressly allow and facilitate fined companies to seek recourse for fines against the responsible managers. Such possibility of recourse will then have to be borne in mind by law enforcers when they determine the amount of the fines and thus also result in a reduction of the quantum of the fines imposed on the company. 